\title{
THE TREATMENT OF PULMONARY HYPERTENSION IN THE CHILDREN WITH CHRONIC OBSTRUCTIVE PULMONARY DISEASE
}

\author{
G. Senatorova, O. Logvinova, L. Chernenko, O. Lupaltsova \\ Paediatrics, Kharkiv National Medical University, Kharkiv, Ukraine
}

Background and aims: Improving the treatment of pulmonary hypertension in children with chronic obstructive pulmonary disease.

Methods: A survey of 70 children, mean age 9,8 $8 \pm 4,5$ months with chronic obstructive pulmonary disease. Pulmonary artery pressure (pLA) was determined before treatment. The 45 patients (main group) received phosphodiesterase inhibitors (FOS) $(2 \mathrm{mg} / \mathrm{kg} /$ day), the control group (25 children) - angiotensin-converting enzyme (ACE) (dose $0.5 \mathrm{mg} / \mathrm{kg} /$ day). In 30, 60, 90 days after initiation of therapy pLA was defined again.

Results: In children of main group pLA was $31,7 \pm 2,3 \mathrm{mmHg}$, in the control group $-31,5 \pm 1,98 \mathrm{mmHg}$. Patients treated with inhibitors of FOS in 30 days pLA decreased to $9,2 \pm 0,7 \%$, which was significantly better than children who received ACE inhibitors $(p<0,05)$. After 60 days in children treated with inhibitors of FOS pLA was $24,47 \pm 1,9 \mathrm{mmHg}$. In the control group pLA was $28,68 \pm 1,9 \mathrm{mmHg}(\mathrm{p}<0,05)$. On the 90 day treatment in children of main group pLA was $23,67 \pm 1,6 \mathrm{mmHg}$, in the control group - 26,98 $22,3 \mathrm{mmHg}$.

Conclusions: In children with chronic obstructive pulmonary disease to effectively reduce the pressure in the pulmonary artery, preventing the progression of hypoxia and fibrosis the phosphodiesterase inhibitors may be used in a dose of $2 \mathrm{mg} / \mathrm{kg} /$ day. 